\title{
Dopamine D1 Binding Potential Predicts Fusiform BOLD Activity during Face-Recognition Performance
}

\author{
Bart Rypma, ${ }^{1}$ Håkan Fischer, ${ }^{2}$ Anna Rieckmann, ${ }^{3}$ Nicholas A. Hubbard, ${ }^{1}$ Lars Nyberg, ${ }^{4}$ and Lars Bäckman ${ }^{3}$ \\ ${ }^{1}$ School of Behavioral and Brain Sciences, University of Texas at Dallas, Richardson, Texas 75080, ${ }^{2}$ Department of Psychology, Stockholm University, \\ SE-106 91 Stockholm, Sweden, ${ }^{3}$ Aging Research Center, Karolinska Institutet, SE-113 30 Stockholm, Sweden, and ${ }^{4}$ Departments of Radiation Sciences and \\ Integrative Medical Biology, Umeå Center for Functional Brain Imaging, Umeå University, SE-901 87 Umeå, Sweden
}

The importance of face memory in humans and primates is well established, but little is known about the neurotransmitter systems involved in face recognition. We tested the hypothesis that face recognition is linked to dopamine (DA) activity in fusiform gyrus (FFG). DA availability was assessed by measuring D1 binding potential (BP) during rest using PET. We further assessed blood-oxygen-leveldependent (BOLD) signal change while subjects performed a face-recognition task during fMRI scanning. There was a strong association between D1 BP and BOLD activity in FFG, whereas D1 BP in striatal and other extrastriatal regions were unrelated to neural activity in FFG. These results suggest that D1 BP locally modulates FFG function during face recognition. Observed relationships among D1 BP, B0LD activity, and face-recognition performance further suggest that D1 receptors place constraints on the responsiveness of FFG neurons.

Key words: Dopamine; face recognition; FMRI; fusiform gyrus; multimodal imaging; PET

\section{Significance Statement}

The importance of face memory in humans and primates is well established, but little is known about the neurotransmitter systems involved in face recognition. Our work shows a role for a specific neurotransmitter system in face memory.

\section{Introduction}

Face processing is mediated by a dedicated functional anatomy (Haxby et al., 2000). Research has established a face-specific network that includes inferior occipital cortex (Gauthier et al., 2000) and fusiform gyrus (FFG; Sergent et al., 1992; Kanwisher et al., 1997) for processing invariant aspects of faces (Gobbini and Haxby, 2007). These regions interact with others (e.g., cingulate cortex, amygdala) to support operations such as new-face encoding, familiar-face recognition, and processing complex meaning in faces (Haxby et al., 2000). Although the neuroanatomy of episodic face recognition is well established, little is known about the neurotransmitter systems involved. Here, we tested the

\footnotetext{
Received April 3, 2015; revised Sept. 13, 2015; accepted Sept. 18, 2015.

Author contributions: H.F., A.R., L.N., and L.B. designed research;H.F. and A.R. performed research; B.R., H.F., and N.A.H. analyzed data; B.R., H.F., A.R., N.A.H., and L.B. wrote the paper.

This work was supported by the University of Texas at Dallas Faculty Development Leave Program, the National Institutes of Health (Grants R01AG029523 and R01AG047972 to B.R.); the Swedish Research Council, Swedish Council for Working Life and Social Research, Swedish Brain Power, an Alexander von Humboldt Research Award, and a donation from the af Jochnick Foundation (L.B. and H.F.), and the Torsten and Ragnar Söderberg's Foundation (L.B. and L.N.). Significant technical and conceptual portions of this work were completed while B.R. was in residence at the Aging Research Center of the Karolinska Institute in Stockholm, Sweden. We thank Saranya Sundaram, Brooke Gomez, and Monroe Turner for technical support.

The authors declare no competing financial interests.

Correspondence should be addressed to Dr. Bart Rypma, School of Behavioral and Brain Sciences, Green Hall, GR41, University of Texas at Dallas, 800 West Campbell Road, Richardson, TX 75080. E-mail: bart.rypma@utdallas.edu.

DOI:10.1523/JNEUROSCI.1298-15.2015

Copyright $\odot 2015$ the authors $\quad 0270-6474 / 15 / 3514702-06 \$ 15.00 / 0$
}

hypothesis that DA plays a principal role in face recognition by assessing associations between DA D1 binding potential (BP) in several brain regions and FFG blood-oxygen-level-dependent (BOLD) activity during face recognition.

Evidence from patient studies, animal research, pharmacologic challenges, specific genetic polymorphisms, and molecular PET and SPECT imaging studies implicate DA in multiple cognitive domains (Bäckman et al., 2006, 2010; Bäckman and Nyberg, 2013; Schultz, 2007a,b). Although most of this work has linked DA to working-memory performance (Williams and Goldman-Rakic, 1995; Luciana and Collins, 1997; Cohen et al., 2002; Cools et al., 2007; Dodds et al., 2009; Landau et al., 2009; Fischer et al., 2010; Cools and D'Esposito, 2011), PET research has associated DA with episodic-memory performance, including verbal and spatial recall, word recognition, and paired-associate learning (Bäckman et al., 2000; Erixon-Lindroth et al., 2005; Cervenka et al., 2008, 2010; Takahashi et al., 2008). Most PET studies linking DA to episodic memory have used markers of striatal and extrastriatal D2 receptor binding. Rodent work indicates that hippocampus D1receptor activation during encoding is critical to establishing persistent episodic-like memories (Rossato et al., 2009; Bethus et al., 2010); however, there is little corresponding human research in episodic memory focused on D1 receptors.

Based on rodent pharmacoimaging, Knutson and Gibbs (2007) asserted that striatal DA D1 activity largely determines the magnitude of the BOLD signal. Similar human DA-BOLD links 
have been demonstrated using presynaptic DA markers and markers of D1 and D2 receptor binding during both working memory and episodic memory performance (Landau et al., 2009; Nyberg et al., 2009; Bäckman et al., 2011; Rieckmann et al., 2011a). Of relevance to the current study, Schott et al. (2008) observed associations between DA release and BOLD activity in ventral striatum during reward-related learning. Distributed DAmediated reward circuitry is known to overlap with the facespecific network (Gurevich and Joyce, 1999; Martinezet al., 2003; Schultz, 2007a,b). One objective of the current study was to assess relationships between $\mathrm{D} 1$ receptor binding and BOLD activity in FFG during face recognition.

Evidence suggests a role for DA in episodic face recognition. Pharmacological data indicate that mesolimbic DA projections extend beyond hippocampus to parahippocampal regions including FFG (Tessitore et al., 2002; Kim et al., 2010). In one study (Kim et al., 2010), subjects underwent fMRI during categorization-task performance after taking either placebo or L-DOPA (a precursor to DA and other catecholamines). These investigators found L-DOPA-related activation increases in one face network region, FFG, suggesting that exogenous DA may modulate FFG BOLD activity. Other studies demonstrate that long-term potentiation mechanisms linked to episodic-memory formation depend on tonic DA-induced hippocampal activity that stimulates ventral tegmentum (VTA), promoting DA release in parahippocampal structures including FFG (Schultz, 2007a,b; Lisman et al., 2011).

We assessed whether DA plays a role in modulation of FFG BOLD activity during face recognition and if this modulation is related to face-recognition performance. We measured FFG D1 receptor $\mathrm{BP}$ using $\mathrm{PET}$ and $\mathrm{BOLD}$ using $\mathrm{fMRI}$ during face recognition. Discriminant validity of FFG D1-BOLD associations was examined by assessing relationships of D1 BP in striatal and extrastriatal regions to FFG BOLD signal amplitude. We further assessed the relationships between BP and BOLD in other facespecific regions (i.e., anterior cingulate cortex, amygdala, and inferior occipital gyrus). Finally, we examined relationships among FFG D1 BP, FFG BOLD, and face-recognition performance. Neurocomputational models (Li et al., 2001, 2010) suggest that increased neural signal gain with DA input yields more distinct memory representations and improved performance. Therefore, we tested whether the degree to which BOLD is modulated by D1 BP in FFG (i.e., the BOLD:DA ratio) predicts facerecognition performance.

\section{Materials and Methods}

Subjects. Twenty right-handed subjects (ages 22-30 years, $\mathrm{M}=25.2$, $\mathrm{SD}=2.2 ; 10$ females) were recruited by local newspaper ads in the Stockholm metropolitan area. All participants reported that they were nonsmokers with no history of drug or alcohol abuse, significant neuropsychiatric disorders, or brain damage. Written informed consent was obtained from the participants and all procedures, including $\left[{ }^{11} \mathrm{C}\right]$ SCH23390 dosage levels, were approved by the Ethics and Radiation Safety Committees of the Karolinska Institute, Stockholm, Sweden. Two participants were excluded from subsequent analyses for behavioral accuracy that was $>2.5$ SDs below the sample mean (overall $\mathrm{M}_{\text {accuracy }}=$ $61 \%$; outlier $1 \mathrm{M}_{\text {accuracy }}=14 \%$; outlier $2 \mathrm{M}_{\text {accuracy }}=18 \%$ ).

Procedure. Participants first completed health and cognitive screening. They then underwent a PET measurement lasting $61 \mathrm{~min}$ to acquire data for D1 BP calculation. On a subsequent occasion, not $>1$ week after the PET scanning, subjects were shown 24 face pictures outside of the MR scanner and instructed to encode them for later retrieval. Approximately 24 min later, during fMRI scanning, subjects were shown the set of 24 previously encoded faces intermixed with a set of 24 new faces in a yes/no recognition test
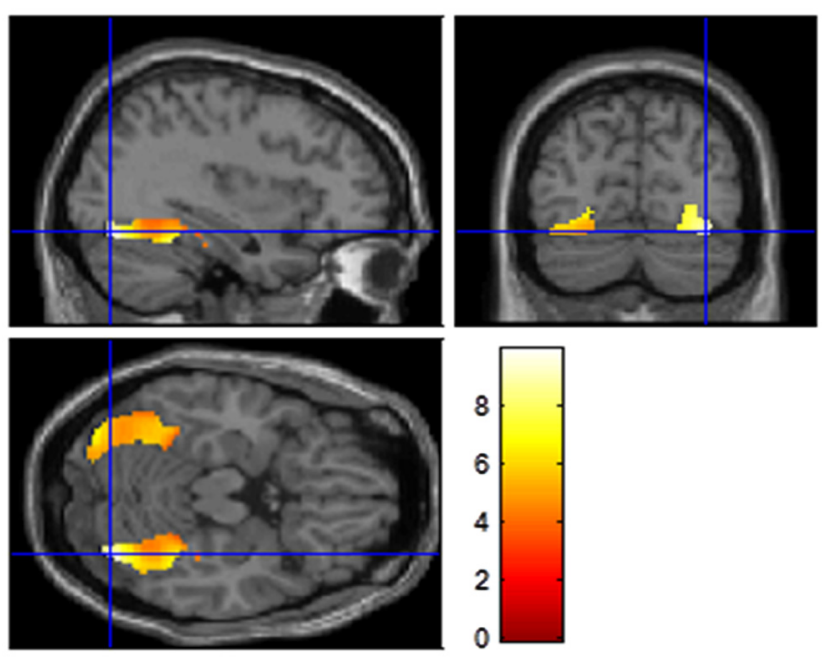

Figure 1. Illustration of bilateral fusiform BOLD activity during episodic face recognition compared with a sensorimotor control task. Threshold $p$-value $=p<0.001$, uncorrected. BOLD activity data are restricted to the fusiform gyrus $\mathrm{ROI}$.

fMRI task. Before fMRI scanning, outside of the scanner, subjects were exposed to 24 faces (half male, half female) during an intentional encoding session with the instructions "You will now see a number of faces. Your task is to remember them for a later test." Approximately $24 \mathrm{~min}$ after conclusion of intentional face encoding, subjects performed a facerecognition task during fMRI scanning. In this task, they alternated between sets of face-recognition trials and sets of sensorimotor buttonpress trials. During the sensorimotor trials, subjects pressed a button each time a cross-hair or circle appeared in the middle of the screen. On each face-recognition trial, a target or distractor face was presented for $2 \mathrm{~s}$ followed by a $500 \mathrm{~ms}$ intertrial interval during which a cross-hair appeared on the screen. Subjects pressed a forefinger-response button to indicate that they recognized the face from the previously encoded set and they pressed a right middle-finger button to indicate that they did not recognize the face. During the sensorimotor trials, the letter " $\mathrm{x}$ " or a circle was presented for $2 \mathrm{~s}$ every $0.5 \mathrm{~s}$ and subjects pressed a button with either finger when one of these target objects appeared.

There were eight face-recognition blocks and eight sensorimotor blocks. In each face-recognition block, subjects viewed six faces, half of which had been presented previously. On the sensorimotor blocks, subjects responded to the letter on half the trials and responded to the circle on half the trials. Each block took $15 \mathrm{~s}$ and there was an interblock interval of $1.25 \mathrm{~s}$. The face-recognition and sensorimotor blocks were in turn grouped into two sets of four blocks each and presented in two separate runs. There were four dummy scans added at the beginning of each run to accommodate initial magnetization. Therefore, each run took $140 \mathrm{~s}$ and the entire procedure lasted $\sim 5$ min including instructions.

fMRI scanning and BOLD analysis. Whole-brain imaging data were acquired on a 1.5 TE Signa Echospeed MR-scanner (GE Medical Systems) using a standard circular 1-channel head coil. T1-weighted 3DSPGR images $\left(\mathrm{TR}=24 \mathrm{~ms}, \mathrm{TE}=6 \mathrm{~ms}\right.$, flip angle $=35^{\circ}$ ) were acquired for anatomical coregistration in 124 contiguous $1.5 \mathrm{~mm}$ coronal slices (image resolution $=256 \mathrm{~mm} \times 256 \mathrm{~mm} \times 186 \mathrm{~mm}$, voxelsize $=0.9$ $\mathrm{mm} \times 0.9 \mathrm{~mm} \times 1.5 \mathrm{~mm})$. Functional images were acquired using a $\mathrm{T} 2 *$-sensitive gradient-echo EPI sequence $(\mathrm{TR}=2.5 \mathrm{~s}$, TE $=40 \mathrm{~ms}$, flip angle $=90^{\circ}$ ). The image volumes had a field of view of $220 \mathrm{~mm} \times 220$ $\mathrm{mm}$, an in-plane resolution of $3.44 \mathrm{~mm} \times 3.44 \mathrm{~mm}$, and contained 32 horizontal, $4-\mathrm{mm}$-thick slices with a $0.5 \mathrm{~mm}$ gap in between each slice. All images were acquired interleaved. During the fMRI session, $104 \mathrm{im}-$ age volumes were obtained across the two scanning runs. All data processing was performed using SPM2 (Wellcome Department of Cognitive Neurology, UK). Functional images were first spatially realigned to the first volume in each time series. Inspection of movement parameters generated during the spatial realignment showed that no participant had moved $>3 \mathrm{~mm}$ or $3^{\circ}$ in any direction during task performance. Vol- 
umes were then normalized to a standard T1 template. Normalized images were spatially smoothed with a Gaussian kernel of $12 \mathrm{~mm}$ fullwidth at half-maximum. High-frequency noise was removed using a band-pass filter at $128 \mathrm{~Hz}$. The hemodynamic response function acted as the lowpass filter.

Face-recognition versus sensorimotor BOLD effects were modeled using a box-car function convolved with a canonical hemodynamic response function. Whole-brain analyses were performed using directional $t$ tests of facerecognition versus sensorimotor periods. Average $\beta$ values were then extracted from regions of interest (ROI), which comprised 4 $\mathrm{mm}$ radius spheres centered around peak activation ( $t$-score) within anatomical brain regions of the WFU Pickatlas (Maldjian et al., 2003). Face-specific ROIs included anterior cingulate, amygdala, FFG, and inferior occipital gyrus.

PET scanning and DA D1 analysis. PET data were collected on an ECAT Exact HR 47 system (Siemens) in 3D mode with trans-axial resolution of $3.8 \mathrm{~mm}$ full-width at half-maximum and a field of view of $4.5 \mathrm{~mm}$ radially $20 \mathrm{~mm}$ from center. Transmission measurements were collected over 10 min with 3 rotating $68 \mathrm{Ge}-$ $68 \mathrm{Ga}$ sources. Then, $300 \mathrm{MBq}$ of the [11C]SCH23390 radioligand was rapidbolus injected into the left antecubital vein. Emission data were collected over the following $51 \mathrm{~min}$ in 13 time frames of increasing duration.

ROIs were manually delineated on each individual's T1-weighted image separately for each hemisphere using the Human Brain Atlas software (Roland et al., 1994). ROIs derived for subsequent analyses included: FFG, ventral striatum, caudate, putamen, hippocampus, amygdala, anterior cingulate cortex, orbital frontal cortex, medial prefrontal cortex, and dorsolateral prefrontal cortex (Rieckmann et al., 2011b). These regions were segmented into gray matter, white matter, and CSF to minimize partial-volume effects. Subsequent analyses with unilateral ROIs did not produce different results (i.e., DA-BOLD relationships); therefore, we aggregated unilateral ROIs across hemispheres.

$B P$ calculation. Time-activity curves (TACs) were calculated from the PET images. For TAC generation, radioactivity was plotted versus time and corrected for decay rate. D1 receptor availability was measured as the $\mathrm{BP}$ of the $\left[{ }^{11} \mathrm{C}\right] \mathrm{SCH} 23390$ radioligand. $\mathrm{BP}$ is defined as the ratio at equilibrium of specifically bound radioligand to that of nondisplaceable radioligand in tissue (Innis et al., 2007) and calculated using the simplified reference tissue model with cerebellum as the reference region (Lammertsma and Hume, 1996) and corrected for partial-volume effects (Meltzer et al., 1990). Therefore, BP may be thought of as density of available D1 receptors indexed by the extent of radioligand occupancy of postsynaptic D1 receptors.

\section{Results}

BOLD activity in fusiform gyrus

BOLD signal contrast between the face-recognition and buttonpress tasks indicated suprathreshold voxels in FFG during facerecognition performance (Fig. 1).

\section{D1-BOLD relationships}

We tested whether D1 BP predicts BOLD signal variability in FFG during face recognition by performing a linear regression of FFG D1 BP estimates and their corresponding BOLD parameter estimates. The standardized correlation coefficient revealed a positive relationship between these variables $\left(\beta=0.62 ; R^{2}=0.38\right.$, $p<0.007$; Fig. 2; regression diagnostics did not identify any unduly influential data points; Belsley et al., 1980). No such rela-

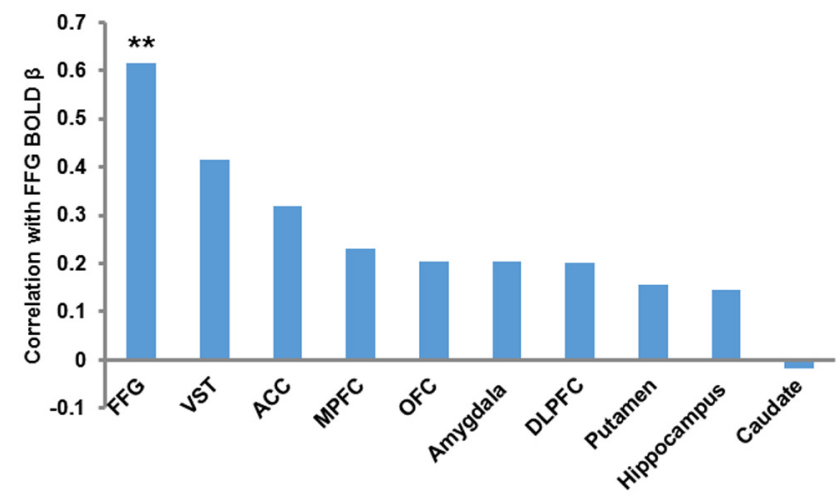

Figure 3. Pearson product-moment correlations between D1 BP $\beta$ and BOLD $\beta$ in all brain regions examined. VST, ventral striatum; $A C C$, anterior cingulate cortex; MPFC, medial prefrontal cortex; OFC, orbital frontal cortex; $P C$, parietal cortex. ${ }^{* *} p<0.001$.

tionships were observed in any other face-specific network regions (i.e., anterior cingulate cortex, amygdala, inferior occipital gyrus; all $p>0.05)$.

To determine whether the relationship between FFG D1 BP and BOLD was unique to DA activity in FFG, we computed corresponding correlations for D1 BP in limbic (anterior cingulate, amygdala, hippocampus), striatal (ventral striatum, caudate, putamen), and prefrontal (e.g., orbito-, dorsolateral, medial) brain regions with FFG BOLD. None of these associations outside of FFG approached significance (all $p>0.10$; Fig. 3).

\section{Relationships to performance}

Overall, $d^{\prime}$ scores indicated that subjects performed well at the group level $(\mathrm{M}=1.25 ; \mathrm{SD}=0.43)$. Among individuals with high $d^{\prime}$ scores (i.e., those subjects whose face-recognition scores were above the median), most of their data points fell above the regression line in the DA-BOLD regression analysis suggesting that, for these subjects, there was greater BOLD activity relative to D1 receptor availability compared with low $d^{\prime}$ performers (i.e., those 


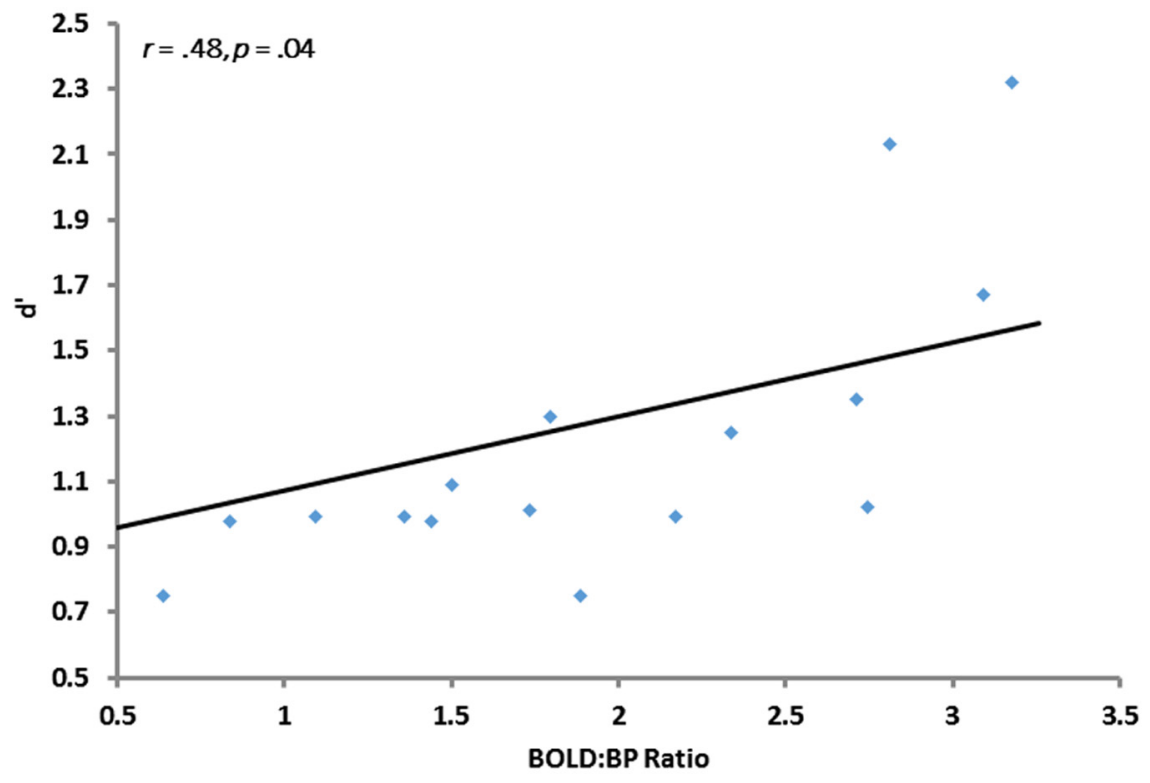

Figure 4. BOLD-BP ratio prediction of face-recognition performance.
2010; Cools and D'Esposito, 2011; Rieckmann et al., 2011a). Such results are thought to reflect a social cognition network for processing emotional and reward-related information conveyed in face stimuli (cf. Siessmeier et al., 2006; Schultz, 2007a,b). Similarly, relationships that we observed between D1 BPs in ventral striatum and anterior cingulate with FFG BOLD, whereas not significant, were probably not trivial. Further research is needed to assess the extent to which distal modulation of FFG can occur during facerecognition processing. The present findings do, however, show that DA affects posterior regions by local modulation of BOLD activity (cf. Jabbi et al., 2013). These results occurred, despite the nearly fivefold reduction in D1 receptors compared with the striatum (Rieckmann et al., 2011b). This link between FFG D1 BP and BOLD suggests that dopamine can act locally to influence face-specific regions within a social cognition network.

The specific D1-BOLD association in subjects whose performance was below the median). Indeed, $d^{\prime}$ was significantly related to individuals' residual scores $(r=0.49$, $p<0.04)$. This relationship indicates that higher BOLD activity relative to D1 receptor availability was associated with better face recognition. It is worth noting that neither BOLD nor D1 receptor availability alone was associated with individual differences in performance $(p>0.05)$. These results are consistent with recent work on the physiological basis of the BOLD response, which suggests an important role for DA in modulation and the activation necessary for distinct memory representations and accurate performance (Knutson and Gibbs, 2007; Karlsson et al., 2009; Li et al., 2009, 2010). On this view, higher neural activity (as approximated with BOLD in the present study) is achieved with lower levels of neural input (as measured by D1 BP in the present study), resulting in better memory performance compared with the case in which the same high activation levels must be achieved with higher levels of neural input (Li et al., 2010)

We formally tested this relationship by first calculating the proportion of subjects' standardized BOLD $\beta$ values relative to their standardized DA BP values (i.e., their BOLD/BP ratio). Figure 4 illustrates that this ratio significantly predicted facerecognition performance $\left(\beta=0.48, R^{2}=0.23, p=0.04\right)$. A Mahalanobis distance analysis identified two outliers in this analysis. These persons were discarded and a separate FFG BOLD:BP ratio model predicting $d^{\prime}$ was run. This model was also significant $\left(\beta=0.57, R^{2}=0.32, p=0.02\right)$.

\section{Discussion}

We examined whether D1 BP predicts neural activity in FFG during episodic face recognition. A strong relationship between D1 BP and BOLD activity in FFG during face recognition was observed. This is the first demonstration of a role of $\mathrm{D} 1$ receptors in face recognition and the first to indicate a D1-BOLD association in FFG.

We observed a region-specific effect wherein D1 BP mediated FFG BOLD activity. This result is consistent with previous work on DA-BOLD links in striatal and associated midbrain regions and their anterior extensions to prefrontal cortex (Schott et al., 2008; Landau et al., 2009; Nyberg et al., 2009; Bäckman et al.,
FFG might reflect the neural demands of the face-recognition task that participants were engaged in during BOLD imaging. Face recognition is known to depend upon FFG function (Kanwisher et al., 1997; Henson et al., 2000). Tasks emphasizing other aspects of face processing (e.g., attractiveness) might elicit D1 BP-BOLD associations in other face-relevant regions (Schultz, 2007a,b). Further research is needed to fully understand the region-specific nature of the associations observed here.

How might DA function at the FFG site to modulate the BOLD response during face recognition? In the mesolimbic DA system, cell bodies extending from VTA to temporal lobe structures as far as FFG might synthesize DA for downstream function during face processing. Similar to DA mechanisms that have been illustrated in midbrain (Knutson and Gibbs, 2007), local DA FFG neurons could function by a process wherein, in response to facerecognition demands, local DA release activates postsynaptic D1 receptors, changing their polarity and increasing their metabolic activity, thereby giving rise to local increases in BOLD activity (Zonta et al., 2003; Hutchison et al., 2013; Hubbard et al., 2015). This metabolic activity, in turn, could stimulate astrocytic mechanisms that mediate neurovascular interactions, which give rise to the BOLD signal. This mechanism is known to lead to expansion of local vascular lumen, as well as increased cerebral blood flow and velocity (Takano et al., 2006; Rossi, 2006). Subsequently, presynaptic DA transporters reuptake unbound DA leading to reversal of postsynaptic polarities, reductions in FFG neural activity, and the accompanying BOLD response (Knutson and Gibbs, 2007). Therefore, the mechanism whereby DA modulates BOLD activity by constraining postsynaptic neural responsiveness in distributed cortical regions such as FFG might resemble its modulatory influences during adaptive cognition (see Schultz, 2007a,b).

DA is a diverse neurotransmitter the functions of which range from somatomotor coordination (Carlsson et al., 1958; Schultz et al., 1989) to motivational (Faure et al., 2005), reward-learning (Schott et al., 2008), and cognitive (Williams and Goldman-Rakic, 1995; Inase et al., 1997; Fallon and Cools, 2014) functions (Schultz, 2007a,b). Such functional diversity might be undergirded by reward 
timing in brain regions critical to the task at hand. Isomorphism between face and reward processing has been suggested by studies demonstrating attractiveness-related variability in face-network regions such as amygdala, which is highly responsive to both attractive and disfigured faces (Kampe et al., 2001; Aharon et al., 2001; Senior, 2003; Liang et al., 2010). Therefore, although D1 BP is associated with FFG BOLD in episodic face recognition in general, it might be linked to neural activity in amygdala and other reward-related regions in processing facial attractiveness.

Our data support the hypothesis that D1 BP modulates BOLD activity by placing constraints on the responsiveness of postsynaptic neurons (Choi et al., 2006; Knutson and Gibbs, 2007). However, they do not rule out other possible mechanisms through which BOLD activity constrains DA activity. For example, similar to mechanisms posited in striatum (Bäckman and Nyberg, 2013), the BOLD response in FFG could modulate DA activity by phasically inhibiting GABAergic neurons. In this view, increased DA activity results from, rather than leads to, increased FFG BOLD activity. A third possibility is that DA and BOLD activity mutually influence one another through the mechanisms discussed above. Finally, we cannot rule out a role for serotonin in this context insofar as its postsynaptic availability is also reflected in the affinity of SCH23390 (Ekelund et al., 2007). However, for several reasons, such potential influences are likely to be negligible (Andersen et al., 1992; Rieckmann et al., 2011b).

We observed higher face-recognition performance for individuals who showed greater BOLD response relative to their DA availability (i.e., those with a higher BOLD-BP ratio). Conversely, those with low BOLD responses relative to DA availability performed less accurately. Similar to prefrontal activity during working memory, subjects for whom higher BOLD activation is attained with lower levels of DA neural input achieve higher gains in the sigmoidal function relating DA input to activation (Li et al., 2001; Li et al., 2010). As has been shown with behavioral associations, larger gain should yield higher neural signal relative to background noise, more distinct memory representations, and higher memory performance (Li and Sikström, 2002; Li et al., 2009). Conversely, subjects for whom higher BOLD activity can only be reached with high levels of DA input should achieve lower gains, less distinct memory representations, and reduced memory performance (Li et al., 2010; Nyberg et al., 2012).

In sum, strong regional associations between D1 BP and BOLD activity in FFG were observed, whereas D1 BP in striatal and other extrastriatal regions were unrelated to BOLD activity in FFG. These results suggest that D1 BP modulates neural function in FFG during face recognition. Relationships among DA, BOLD activity, and performance further suggest that the extent to which DA availability drives FFG neural activity is linked to facerecognition accuracy.

\section{References}

Aharon I, Etcoff N, Ariely D, Chabris CF, O'Connor E, Breiter HC (2001) Beautiful faces have variable reward value: $\mathrm{fMRI}$ and behavioral evidence. Neuron 32:537-551. CrossRef Medline

Andersen PH, Grønvald FC, Hohlweg R, Hansen LB, Guddal E, Braestrup C, Nielsen EB (1992) NNC-112, NNC-687 and NNC-756, new selective and highly potent dopamine D1 receptor antagonists. Eur J Pharmacol 219:45-52. CrossRef Medline

Bäckman L, Nyberg L (2013) Dopamine and training-related working-memory improvement. Neurosci Biobehav Rev 37:2209-2219. CrossRef Medline

Bäckman L, Karlsson S, Fischer H, Karlsson P, Brehmer Y, Rieckmann A, MacDonald SW, Farde L, Nyberg L (2011) Dopamine $\mathrm{D}_{1}$ receptors and age differences in brain activation during working memory. Neurobiol Aging 32:1849-1856. CrossRef Medline

Bäckman L, Small BJ, Wahlin Å, Larsson M (2000) Cognitive functioning in very old age. In: The handbook of aging and cognition, Ed 2 (Craik FIM, Salthouse SA, eds), pp 499-558. Mahwah, NJ: Erlbaum.

Bäckman L, Nyberg L, Lindenberger U, Li SC, Farde L (2006) The correlative triad among aging, dopamine, and cognition: current status and future prospects. Neurosci Biobehav Rev 30, 791-807. CrossRef Medline

Bäckman L, Lindenberger U, Li SC, Nyberg L (2010) Linking cognitive aging to alterations in dopamine neurotransmitter functioning: recent data and future avenues. Neurosci Biobehav Rev 34:670-677. CrossRef Medline

Belsley DA, Kuh E, Welsch RE (1980) Regression diagnostics: Identifying influential data and sources of collinearity. Hoboken, NJ: Wiley.

Bethus I, Tse D, Morris RG (2010) Dopamine and memory: Modulation of the persistence of memory for novel hippocampal NMDA receptordependent paired associates. J Neurosci 30:1610-1618. CrossRef Medline

Carlsson A, Waldeck B (1958) A fluorimetric method for the determination of dopamine (3-hydroxytyramine). Acta Physiol Scand 44:293-298. CrossRef Medline

Cervenka S, Bäckman L, Cselényi Z, Halldin C, Farde L (2008) Associations between dopamine D2-receptor binding and cognitive performance indicate functional compartmentalization of the human striatum. Neuroimage 40:1287-1295. CrossRef Medline

Cervenka S, Varrone A, Fransén E, Halldin C, Farde L (2010) PET studies of D2-receptor binding in striatal and extrastriatal brain regions: Biochemical support in vivo for separate dopaminergic systems in humans. Synapse 64:478-485. CrossRef Medline

Choi JK, Chen YI, Hamel E, Jenkins BG (2006) Brain hemodynamic changes mediated by dopamine receptors: Role of the cerebral microvasculature in dopamine-mediated neurovascular coupling. Neuroimage 30: 700-712. CrossRef Medline

Cohen JD, Braver TS, Brown JW (2002) Computational perspectives on dopamine function in prefrontal cortex. Curr Opin Neurobiol 12:223229. CrossRef Medline

Cools R, Sheridan M, Jacobs E, D'Esposito M (2007) Impulsive personality predicts dopamine-dependent changes in frontostriatal activity during component processes of working memory. J Neurosci 27:5506-5514. CrossRef Medline

Cools R, D'Esposito M (2011) Inverted-U-shaped dopamine actions on human working memory and cognitive control. Biol Psychiatry 69:e113e125. CrossRef Medline

Dodds CM, Clark L, Dove A, Regenthal R, Baumann F, Bullmore E, Robbins TW, Müller U (2009) The dopamine D2 receptor antagonist sulpiride modulates striatal BOLD signal during the manipulation of information in working memory. Psychopharmacology 207:35-45. CrossRef Medline

Ekelund J, Slifstein M, Narendran R, Guillin O, Belani H, Guo NN, Hwang Y, Hwang DR, Abi-Dargham A, Laruelle M (2007) In vivo DA D(1) receptor selectivity of NNC 112 and SCH 23390. Mol Imaging Biol 9:117-125. CrossRef Medline

Erixon-Lindroth N, Farde L, Wahlin TB, Sovago J, Halldin C, Bäckman L (2005) The role of the striatal dopamine transporter in cognitive aging. Psychiatry Research: Neuroimaging 138:1-12. CrossRef Medline

Fallon SJ, Cools R (2014) Reward acts on the pFC to enhance distractor resistance of working memory representations. J Cogn Neurosci 26:28122826. CrossRef Medline

Faure A, Haberland U, Condé F, El Massioui N (2005) Lesion to the nigrostriatal dopamine system disrupts stimulus-response habit formation. J Neurosci 25:2771-2780. CrossRef Medline

Fischer H, Nyberg L, Karlsson S, Karlsson P, Brehmer Y, Rieckmann A, MacDonald SW, Farde L, Bäckman L (2010) Simulating neurocognitive aging: effects of a dopaminergic antagonsit on brain activity during working memory. Biol Psychiatry 67:575-580. CrossRef Medline

Gauthier I, Tarr MJ, Moylan J, Skudlarski P, Gore JC, Anderson AW (2000) The fusiform "face area" is part of a network that processes faces at the individual level. J Cogn Neurosci 12:495-504. CrossRef Medline

Gobbini MI, Haxby JV (2007) Neural systems for recognition of familiar faces. Neuropsychologia 45:32-41. CrossRef Medline

Gurevich EV, Joyce JN (1999) Distribution of dopamine D3 receptor expressing neurons in the human forebrain: comparison with D2 receptor expressing neurons. Neuropsychopharmacology 20:60-80. CrossRef Medline

Haxby JV, Hoffman EA, Gobbini MI (2000) The distributed human neural system for face perception. Trends Cogn Neurosci 4:223-233. CrossRef Medline

Henson R, Shallice T, Dolan R (2000) Neuroimaging evidence for disso- 
ciable forms of repetition priming. Science 287:1269-1272. CrossRef Medline

Hubbard NA, Turner M, Hutchison JL, Ouyang A, Strain J, Oasay L, Sundaram S, Davis SL, Remington G, Brigante RM, Huang H, Hart Jr J, Frohman TC, Frohman E, Biswal BB, Rypma B (2015) Multiple sclerosis-related white matter microstructural change alters the BOLD hemodynamic response. J Cereb Blood Flow and Metab, in press.

Hutchison JL, Lu H, Rypma B (2013) Neural mechanisms of age-related slowing: the $\triangle \mathrm{CBF} / \triangle \mathrm{CMRO} 2$ ratio mediates age-differences in BOLD signal and human performance. Cereb Cortex 23:2337-2346. CrossRef Medline

Inase M, Li BM, Tanji J (1997) Dopaminergic modulation of neuronal activity in the monkey putamen through D1 and D2 receptors during a delayed Go/Nogo task. Exp Brain Res 117:207-218. CrossRef Medline

Innis RB, Cunningham VJ, Delforge J, Fujita M, Gjedde A, Gunn RN, Holden J, Houle S, Huang SC, Ichise M, Iida H, Ito H, Kimura Y, Koeppe RA, Knudsen GM, Knuuti J, Lammertsma AA, Laruelle M, Logan J, Maguire RP, Mintun MA, Morris ED, Parsey R, Price JC, Slifstein M, Sossi V, Suhara T, Votaw JR, Wong DF, Carson RE (2007) Consensus nomenclature for in vivo imaging of reversibly binding radioligands. J Cereb Blood Flow Metab 27:1533-1539. CrossRef Medline

Jabbi M, Nash T, Kohn P, Ianni A, Rubinstein D, Holroyd T, Carver FW, Masdeu JC, Kippenhan JS, Robinson SE, Coppola R, Berman KF (2013) Midbrain presynaptic dopamine tone predicts sustained and transient neural response to emotional salience in humans: fMRI, MEG and FDOPA PET. Mol Psychiatry 18:4-6. CrossRef Medline

Kampe KK, Frith CD, Dolan RJ, Frith U (2001) Reward value of attractiveness and gaze. Nature 413:589. CrossRef Medline

Kanwisher N, McDermott J, Chun MM (1997) The fusiform face area: A module in human extrastriate cortex specialized for face perception. J Neurosci 17:4302-4311. Medline

Karlsson S, Nyberg L, Karlsson P, Fischer H, Thilers P, Macdonald S, Brehmer Y, Rieckmann A, Halldin C, Farde L, Backman L (2009) Modulation of striatal dopamine D1 binding by cognitive processing. Neuroimage 48: 398-404. CrossRef Medline

Kim N, Goel PK, Tivarus ME, Hillier A, Beversdorf DQ (2010) Independent component analysis of the effect of L-dopa on fMRI of language processing. PLoS One 5:e11933. CrossRef Medline

Knutson B, Gibbs SE (2007) Linking nucleus accumbens dopamine and blood oxygenation. Psychopharmacology 191:813-822. CrossRef Medline

Lammertsma AA, Hume SP (1996) Simplified reference tissue model for PET studies. Neuroimage 4:153-158. CrossRef Medline

Landau SM, Lal R, O’Neil JP, Baker S, Jagust WJ (2009) Striatal dopamine and working memory. Cereb Cortex 19:445-454. CrossRef Medline

Liang X, Zebrowitz LA, Zhang Y (2010) Neural activation in the "reward circuit" shows a nonlinear response to facial attractiveness. Soc Neurosci 5:320-334. CrossRef Medline

Li SC, Lindenberger U, Bäckman L (2010) Dopaminergic modulation of cognition across the life span. Neurosci Biobehav Rev 34:625-630. CrossRef Medline

Li SC, Lindenberger U, Sikström S (2001) Aging cognition: From neuromodulation to representation to cognition. Trends Cogn Sci 5:479-486. CrossRef Medline

Li SC, Sikström S (2002) Integrative neurocomputational perspectives on cognitive aging, neuromodulation, and representation. Neurosci Biobehav Rev 26:795-808. CrossRef Medline

Li SC, Lindenberger U, Nyberg L, Heekeren HR, Bäckman L (2009) Dopaminergic modulation of cognition in human aging. In: Imaging the aging brain (Jagust W, D’Esposito M, eds), pp 71-91. New York: OUP.

Lisman J, Grace AA, Duzel E (2011) A neohebbian framework for episodic memory; role of dopamine dependent late LTP. Trends Neurosci 34:536547. CrossRef Medline

Luciana M, Collins PF (1997) Dopaminergic modulation of working memory for spatial but not object cues in normal humans. J Cogn Neurosci 9:330-347. CrossRef Medline

Maldjian JA, Laurienti PJ, Kraft RA, Burdette JH (2003) An automated method for neuroanatomical and cytoarchitectonic atlas-based interrogation of fMRI data sets. Neuroimage 19:1233-1239. CrossRef Medline

Martinez D, Slifstein M, Broft A, Mawlawi O, Hwang DR, Huang Y, Cooper T, Kegeles L, Zarahn E, Abi-Dargham A, Haber SN, Laruelle M (2003) Imaging human mesolimbic dopamine transmission with positron emis- sion tomography: Amphetamine-induced dopamine release in the functional subdivisions of the striatum. J Cereb Blood Flow Metab 23:285300. Medline

Meltzer CC, Leal JP, Mayberg HS, Wagner HN Jr, Frost JJ (1990) Correction of PET data for partial volume effects in human cerebral cortex by MR imaging. Journal of Computer Assisted Tomography 14:561-570. CrossRef Medline

Nyberg L, Lövdén M, Riklund K, Lindenberger U, Bäckman L (2012) Memory aging and brain maintenance. Trends Cogn Sci 16:292-305. CrossRef Medline

Nyberg L, Andersson M, Forsgren L, Jakobsson-Mo S, Larsson A, Marklund P, Nilsson LG, Riklund K, Bäckman L (2009) Striatal dopamine D2 binding is related to fronal BOLD response during updating of long-term memory representations. Neuroimage 46:1194-1199. CrossRef Medline

Rieckmann A, Karlsson S, Fischer H, Bäckman L (2011a) Caudate dopamine D1 receptor density is associated with individual differences in fronto-parietal connectivity during working memory. J Neurosci 31: 14284-14290. CrossRef Medline

Rieckmann A, Karlsson S, Karlsson P, Brehmer Y, Fischer H, Farde L, Nyberg L, Bäckman L (2011b) Dopamine D1 receptor associations within and between dopaminergic pathways in younger and elderly adults: links to cognitive performance. Cereb Cortex 21:2023-2032. CrossRef Medline

Roland PE, Graufelds CJ, W Hlin J, Ingelman L, Andersson M, Ledberg A, Pedersen J, Akerman S, Dabringhaus A, Zilles K (1994) Human brain atlas: For high-resolution functional and anatomical mapping. Hum Brain Mapp 1:173-184. CrossRef Medline

Rossato JI, Bevilaqua LR, Izquierdo I, Medina JH, Cammarota M (2009) Dopamine controls persistence of long-term memory storage. Science 325:1017-1020. CrossRef Medline

Rossi DJ (2006) Another BOLD role for astrocytes: Coupling blood flow to neural activity. Nat Neurosci 9:159-161. CrossRef Medline

Schott BH, Minuzzi L, Krebs RM, Elmenhorst D, Lang M, Winz OH, Seidenbecher CI, Coenen HH, Heinze HJ, Zilles K, Düzel E, Bauer A (2008) Mesolimbic fMRI activations during reward anticipation correlate with reward-related ventral striatal dopamine release. J Neurosci 28:1431114319. CrossRef Medline

Schultz W (2007a) Behavioral dopamine signals. Trends Neurosci 30:203210. CrossRef Medline

Schultz W (2007b) Multiple dopamine functions at different time courses. Annu Rev Neurosci 30:259-288. CrossRef Medline

Schultz W, Romo R, Scarnati E, Sundström E, Jonsson G, Studer A (1989) Saccadic reaction times, eye-arm coordination and spontaneous eye movements in normal and MPTP-treated monkeys. Exp Brain Res 78: 253-267. CrossRef Medline

Senior C (2003) Beauty in the brain of the beholder. Neuron 38:525-528. CrossRef Medline

Sergent J, Ohta S, MacDonald B (1992) Functional neuroanatomy of face and object processing: a positron emission tomography study. Brain 115: 15-36. CrossRef Medline

Siessmeier T, Kienast T, Wrase J, Larsen JL, Braus DF, Smolka MN, Buchholz HG, Schreckenberger M, Rösch F, Cumming P, Mann K, Bartenstein P, Heinz A (2006) Net influx of plasma 6-[18F] fluoro-L-DOPA (FDOPA) to the ventral striatum correlates with prefrontal processing of affective stimuli. Eur J Neurosci 24:305-313. CrossRef Medline

Takahashi H, Kato M, Takano H, Arakawa R, Okumura M, Otsuka T, Kodaka F, Hayashi M, Okubo Y, Ito H, Suhara T (2008) Differential contributions of prefrontal and hippocampal dopamine D-1 and D-2 receptors in human cognitive functions. J Neurosci 28:12032-12038. CrossRef Medline

Takano T, Tian GF, Peng W, Lou N, Libionka W, Han X, Nedergaard M (2006) Astrocyte-mediated control of cerebral blood flow. Nat Neurosci 9:260-267. CrossRef Medline

Tessitore A, Hariri AR, Fera F, Smith WG, Chase TN, Hyde TM, Weinberger DR, Mattay VS (2002) Dopamine modulates the response of the human amygdala: a study in Parkinson's disease. J Neurosci 22:9099-9103. Medline

Williams GV, Goldman-Rakic PS (1995) Modulation of memory fields by dopamine D1 receptors in prefrontal cortex. Nature 376:572-575. CrossRef Medline

Zonta M, Angulo MC, Gobbo S, Rosengarten B, Hossman KA, Pozzan T, Carmignoto G (2003) Neuron-to-astrocyte signaling is central to the dynamic control of brain microcirculation. Nat Neurosci 6:43-50. CrossRef Medline 